\title{
ANALISIS PENGARUH INFRASTRUKTUR JALANDAN TEKNOLOGI INFORMASI DAN KOMUNIKASI (TIK) TERHADAP PEMBANGUNAN MANUSIA DI WILAYAH TIMUR INDONESIA
}

\author{
Rhio Eka Saputra ${ }^{1)^{*}}$, Hefrizal Handra ${ }^{2)}$, Elvina Primayesa ${ }^{3)}$ \\ ${ }^{1)^{* 2 / 3}}$ Fakultas Ekonomi Universitas Andalas, Padang, Indonesia \\ Email: saputraekarhio@gmail.com
}

\begin{abstract}
Abstrak: Isu utama pada perkembangan ekonomi saat ini bukan hanya terbatas pada seberapa tinggi tingat pertumbuhan ekonomi. Lebih dalam lagi, masalah yang ada adalah bagaimana meningkatkan pembangunan manusia itu sendiri. Pembangunan manusia indonesia wilayah timur masih sangat timpang dibandingkan dengan wilayah barat. Banyak kebijakan yang dijalankan untuk meningkatkan taraf pembangunan manusia wilayah timur dalam mengejar ketertinggalan. Salah satunya dengan pembangunan infastruktur dasar dan infrastruktur penunjang. Penelitian ini menggunakan rasio jalan dan IP-TIK sebagai alat untuk mengalasis sejauh mana pengaruh variabel tersebut dalam mempengaruhi pembangunan manusia dengan menggunakan analisis regresi data panel dengan model random effect. Hasil penelitian menemukan bahwa IP-TIK memiliki pengaruh yeng lebih tinggi dibandingkan akses jalan dalam meningkatkan indeks pembangunan manusia di wilayah timur Indonesia. Hal ini diperkuat dengan kondisi geograsfis Indoensia timur yang sangat sulit dijangkau dengan akses jalan dan IP-TIK dianggap sebagai solusi yang lebih efektif.
\end{abstract}

Kata Kunci: IPM, Infrastruktur, Jalan, IP-TIK

Abstract:The main issue in current economic development nowadays is not just limited to economic growth. More deeply, the problem is how to increase human development itself. Human development in the eastern Indonesia region is still very unequal compared to the western region. Many policies have been implemented to increase the level of human development in the eastern region is catching up withinequality. One of them is by building main infrastructure and secondary infrastructure. This Research uses the road ratio and ICT Development Index as a tool to analyze the extent to which these variables influence human development by using panel data regression analysis with a random effect model. The results of the study found that ICT Development Index has a higher effect than road access in increasing the human development index in eastern Indonesia. This happens with the geographical conditions of eastern Indonesia which are very difficult to reach with road access and ICT Development Indexclaimed as a more effective solution.

Keywords : HDI, Infrastrcuture, Roads system, ICT

\section{A. PENDAHULUAN}

Dalam Laporan Human Development Report (HDR) yang dibuat oleh United Nations Development Programme (UNDP) Tahun 2019 menyebutkan bahwa tantangan yang harus di hadapi negara negara di dunia khususnya negara berkembang pada abad ke-21 ini adalah bukan hanya masalah pertumbuhan ekonomi danusaha mencapai ekonomi yang stabil. Menurut UNDP masalah utama yang menjadi perhatian adalah kualitas pembangunan manusia yang semakin lebar antara negara maju dengan negara berkembang.

Negara - negara maju cenderung mempunyai kualitas sumber daya manusia yang lebih baik dibandingkan dengan negara negara berkembang yang diukur melalui indeks pembangunan manusia. Hal tersebut disebabkan karena negara negara maju terlebih dahulu merasakan arus modernisasi dan infrastruktur yang lebih maju (Mohanty, 2016) serta peran pemerintah yang lebih maksimal dalam menjamin akses sosial bagi masyarakatnya sehingga dapat menjanjikan 
kualitas manusia yang baik pula. Berbeda dengan negara berkembang dimana indeks pembangunan mansuia yang diukur melalui suatu indeks komposit yaitu, akses pendidikan, kesehatan, serta pendapatan yang masih rendah sehingga menghasilkan pembangunan yang rendah pula.

Untuk mendukung akses kesejahteraan, pendidikan, dan kesehatan yang baik maka negara berkembang memerlukan infrastrukturdasar yang memadai. Pembangunan infrastruktur dasar dianggapaspek vital dalam mencapai pembangunan manusia yang komprehensif (Sapkota, 2014). Kurangnya akses terhadap infrastruktur atau kemiskinan infastruktur dapat merusak pembangunan manusia yang inklusif(Tanaka, 2012). Oleh karena itu, untuk mempersempit kesenjangan antara negara maju dan berkembang adalah dengan mendorong aspek infrastruktur dasar yaitu akses listrik, air minum, dan jaringan jalan.

Sejak dunia memasuki era revolusi industri 4.0 pada tahun 2000-an dimana ditandai dengan adopsi teknologi informasi/internet hampir disetiap aspek kehidupan (Internet of things) secara fundamental dapat berpotensi meningkatkan efisiensi dan mendorong inovasi dalam skala yang lebih besar sejalan dengan infastruktur yang sudah ada.Negara seperti Jepangdan Korea Selatan telah membuktikan, dengan pembangunan infrasruktur dan memanfaatkan teknologi suatu negara dapat mempercepat pertumbuhan dan pembangunan ekonomi (Minah, 2014). Bagi negara berkembang, akses internet atau teknologi informasi merupakan salah satu jalan keluar untuk mempersempit kesenjangan sumber daya manusia hal ini dikarenakan teknologi informasi yang tidak mengenal aspek ruang/geografis.

Jika dilihat kondisi pembangunan manusia, pada tahun 2018 Indonesia berada pada peringkat 111 dari 189 negara dengan tingkat pembangunan manusia pada level 0,707 sedangkan untuk wilayah ASEAN Indonesia berada pada peringkat 6 tergolong kepada indeks pembangunan manusia (IPM) dengan level sedang. Namun, secara level peningkatan, Indonesia tergolong salah satu negara terbaik dalam peningkatan level pembangunan manusia.

Dibalik peningkatan level yang baik,masih terdapat masalah kesenjangan pembangunan manusia yang masih lebar khususnya provinsi - provinsi di wilayah timur dibandingkan dengan wilayah barat Indonesia. Pembangunan masih terpusat di wilayah barat khususnya Daerah Khusus Ibukota Jakarta. Berbagai kebijakan telah dilakukan salah satunya dengan pemberian otonomi daerah dan pembangunan infrastruktur dasar (akses air bersih, akses listrik, dan akses jalan) pada setiap provinsi sampai ke daerah 3T (terdepan, terpencil, terluar). Namun kebijakan tersebut masih belum mampu menurunkan angka kesenjangan pembnangunan wilayah dan pembangunan manusia.

Masuknya era revolusi industri 4.0 dianggap menjadi salah satu harapan barudalam mendorong pembangunan manusia karena menyangkut setiap aspek kehidupan dalam pemenuhan kebutuhan dasar (Elfindri, 2019) khususnya bagi wilayah yang mempunyai akses infrastruktur yang rendah. Perkembangan ilmu pengetahuan dan teknologi infromasi dan komunikasi mendorong percepatan proses pembangunan melalui pergantian pola kerja yang awalnyamengandalkan tenaga manusia kemudian digantikan oleh mesin dan komputerisasi canggih sehingga berdampak pada efektifitas, efisiensi, kualitas serta kualitas dari rangkaian aktifitas pembangunan ekonomi dan pada akhirnya berakibat padapercepatanlajupertumbuhan ekonomi (Maulana, 2013).

Yakunina dan Bychkov (2015) melakukan penelitian pada 15 negara berkembang dan negara maju menemukan bahwa TIK dan pertumbuhan ekonomi mempunyai pengaruh yang siginfikan terhadap IPM baik untuk negara maju, berkembang dan negara terbelakang. Colecchia and Schreyer (2002) melakukan penelitian dan menyimpulkan bahwa dari sampel negara - negara yang dijadikan objek penelitian bahwa TIK yang diukur dalam indeks teknologi informasi dan teknologi (IP-TIK) mempunyai pengaruh yang positif dan signifkan untuk mendorong pembangunan manusia.Asongu and Le Roux (2017) dalam penelitiannya khusus melihat pengaruh telekomunikasi terhadap aspek pendidikan di Sub-Sahara Afrika menemukan 
bahwa teknologi informasi dan telekomunikasi mempunyai pengaruh yang sangat besar dan medongkrak rata rata indeks pembangunan manusia. Ngwenyama (2006) dalam penelitiannya menemukan bahwa investasi TIK di negara negara afrika harus sejalan dengan pembangunan infrastruktur dasar.

Hasil sedikit berbeda ditemukan dalam penelitian(Bankole, Shirazi, and Brown, 2011) penelitiannya menemukan hasil yang beragam yang dilakukan pada 51 negara di dunia dan membagi menjadi tiga kategori, yaitu negara maju, negara pendapatan sedang, dan negara pendapatan rendah. Penelitian ini menemukan bahwa pembangunan dan investasi TIK pada sektor pendidikan, kesehatan dan pendapatan berdampak positif dan signifikan pada negara maju. Pada negara pendapatan sedang dan pendapatan rendah, Investasi TIK berdampak positif dan siginfikan pada aspek pendapatan dan pendidikan saja, namun kesehatan tidak.

Berdasarkan pada penjelasan di atas maka timbullah pertanyaan, apakah peningkatan pendapatan, infrastruktur dasar, dan teknologi informasi dapat memberikan dampak yang cukup signifkan dalam menekan kesenjangan yang terjadi padawilayah timur Indonesia? Untuk itu, penelitian ini akan melihat pengaruh pembangunan Jalan dan adopsi Teknologi informasi dan komunikasi terhadap pembangunan manusia di 13 Provinsi Timur Indonesia.

\section{B. METODE PENELITIAN}

Penelitian ini merupakan jenis penelitian deskriptif dan analisa inferensia. Analisis deskriptif untuk melihat gambaran umum pembangunan manusia di Indonesia dan analisis inferensia yang digunakan dalam penelitian ini adalah analisis regresi panel data, yaitu gabungan dari time series dan cross section(Gujarati, 2014) yang digunakan untuk menjelaskan pengaruh Pendapatan perkapita, Rasio jalan, dan Indeks Pembangunan Teknologi Informasi dan Komunikasi terhadap Indeks Pembangunan Manusia di Indonesia. Cakupan wilayah dalam penelitian ini terdiri dari 13 provinsi di timurIndonesia selama kuran waktu 2017 sampai dengan 2019.

Analisis regresi data panel yang digunakan yaitu:

$$
\begin{aligned}
& Y_{\text {it }}=\beta_{0}+\beta_{1} X_{1 i t}+\beta_{2} X_{2 i t}+\ldots+\beta_{k} X_{k i t}+\varepsilon_{i t} \\
& \varepsilon_{i t}=\mu+v_{i t} \\
& \text { dimana, } \\
& \text { i : urut individu, } \\
& \text { t : : urut waktu, } \\
& \beta_{0} \quad: \text { koefisien intersep, } \\
& \beta 1,2, \ldots, k \quad \text { : koefisien slope, } \\
& \text { Yit } \quad \text { : variabel dependen individu ke-i pada waktu ke-t, } \\
& X_{\text {it }} \quad \text { : variable independen individu ke-I pada waktu ke-t, } \\
& \varepsilon_{\text {it }} \quad: \text { komponen interferensi, } \\
& \mu_{\mathrm{i}} \quad \text { : efek individu, } \\
& \text { vit : variable acak. }
\end{aligned}
$$

Sehingga, pada penelitian ini model yang akan diestimasi adalah sebagai berikut:

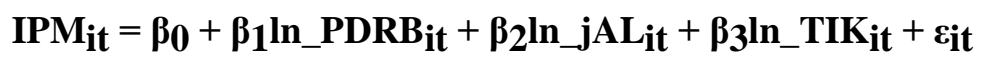

dimana,

IPMit : Indeks Pembangunan Manusia provinsi i, pada tahun t,

PDRBit : PDB Perkapita provinsi i, pada tahun $\mathrm{t}$,

JALit : Rasio Jalan per luas wilayah provinsi i, pada tahun $\mathrm{t}$, 
TIKit : Indeks Pembangunan Teknologi, Informasi, dan Komunikasi provinsi i, padatahun $\mathrm{t}$.

Tabel 1. Definisi Operasional Variabel

\begin{tabular}{|c|c|c|}
\hline Data & Kriteria & Indikator \\
\hline Pembangunan Manusia & Indeks & Pembangunan \\
\hline Kesejahteraan & Pendapatan & PDRB Perkapita Provinsi \\
\hline Infrastruktur Dasar & Jalan & $\begin{array}{l}\text { Rasio Jalan Per Luas } \\
\text { Wilayah }\end{array}$ \\
\hline Infrastruktur Sekunder & $\begin{array}{l}\text { Tekonologi Informasi } \\
\text { dan Komunikasi }\end{array}$ & $\begin{array}{lc}\text { Indeks } & \text { Pembangunan } \\
\text { Teknologi } & \text { Infromasi dan } \\
\text { Komunikasi per Provinsi }\end{array}$ \\
\hline
\end{tabular}

Terdapat tiga model dalam proses estimasi parameter pada analisis regresi data panel (Baltagi, 2015), yakni:

1. Common Effect Model (CEM)

Model ini dikenal sebagai Pooled Regression Model atau Pooled Least Square (PLS) (Gujarati, 2014). Model CEM mengasumsikan bahwa intersep masing-masing variabel adalah sama, begitu juga dengan slope koefisien untuk semua unit individu dan rentet waktu (Melliana, 2013). Dengan kata lain, model ini mengabaikan variasi yang muncul dari individu dan waktu. Persamaan dari model ini dapat diformulasikan sebagai berikut:

$$
Y_{i t}=\beta_{0}+\beta_{1} X_{1 i t}+\beta_{2} X_{2 i t}+\ldots+\beta_{k} X_{k i t}+v_{i t}
$$

\section{Fixed Effect Model (FEM)}

Berbeda dengan CEM, FEM mengakomodasi adanya perbedaan efek yang diberikan antar individu. Dengan berbedanya efek yang diberikan antar individu makan intersep yang dihasilkan untuk tiap individu akan berbeda. Persamaan Fixed Effect Model (FEM) dapat diformulasikan sebagai berikut:

$$
Y_{i t}=\alpha_{i}+\beta_{1} X_{1 i t}+\beta_{2} X_{2 i t}+\ldots+\beta_{k} X_{k i t}+\varepsilon_{i t}
$$

Indeks $i$ pada intersep $\left(\alpha_{\mathrm{i}}\right)$ digunakan untuk menyatakan bahwa intersep dari masing-masing individu berbeda.

3. Random Effect Model (REM)

Model REM memperkirakan variable error dapat saling berhubungan antara waktu dan antar individu. Perbedaan tersebut diakomodir melalui error. Persamaan REM dapat diformulasikan sebagai berikut:

$$
Y_{i t}=\beta_{0}+\beta_{1} X_{1 i t}+\beta_{2} X_{2 i t}+\ldots+\beta_{k} X_{k i t}+\varepsilon_{i t}
$$

dimana,

$\varepsilon_{i t}=\mu_{i}+v_{i t}$

Selanjutnya, dari ketiga model tersebut dilakukan pemilihan model terbaik dan paling sesuai. Uji yang dilakukan untuk menentukan model terbaik dari 3 model tersebut yaitu: 
1. Uji Chow

Uji ini digunakan untuk mengetahui apakah regresi data panel fixed effect model (FEM) lebih baik daripada common effect model (CEM). Hipotesis uji chow adalah sebagai berikut:

$\mathrm{H}_{0}: \mu_{1}=\mu_{2}=\cdots=\mu_{\mathrm{n}}=0(\mathrm{CEM})$

$\mathrm{H}_{1}$ : Paling tidak ada satu $\mu_{\mathrm{i}} \neq 0$ untuk $\mathrm{i}=1,2, \ldots, \mathrm{n}(\mathrm{FEM})$

Nilai dari uji chow akan dibandingkan dengan distribusi $\mathrm{F}$, jika nilai F-statistik lebih besardari F-tabel atau nilai peluang lebih kecil dari tingkat signifikansi $(\alpha=0.05)$ maka FEM lebih baik dibandingkan dengan CEM.

2. Uji Hausman

Uji Hausman digunakan untuk mengetahui model mana yang lebih baik antara fixed effect model (FEM) atau random effect model (REM). Dengan hipotesis sebagai berikut:

$\mathrm{H}_{0}: \operatorname{cov}\left(\varepsilon_{\mathrm{it}}, \mathrm{X}_{\mathrm{it}}\right)=0(\mathrm{REM})$

$\mathrm{H}_{1}: \operatorname{cov}\left(\varepsilon_{\mathrm{it}}, \mathrm{X}_{\mathrm{it}}\right) \neq 0(\mathrm{FEM})$

Nilai dari uji hausman akan dibandingkan dengan distribusi chi-squere, jika nilai $\chi^{2}$ statistik lebih besar dari $\chi^{2}$-tabel atau nilai peluang lebih kecil dari tingkat signifikansi $(\alpha=0.05)$ maka FEM lebih baik dibandingkan dengan REM.

3. Uji Breush-Pagan Lagrange Multiplier (LM)

Uji ini digunakan untuk mengetahui apakah random effect model (REM) lebih baikdaripada common effect model (CEM). Hipotesis uji Breush-Pagan Lagrange Multiplier (LM) adalah sebagai berikut:

$\mathrm{H}_{0}: \sigma \mu=0$ (CEM)

$\mathrm{H}_{1}: \sigma \mu \neq 0(\mathrm{REM})$

Nilai dari uji Breush-Pagan Lagrange Multiplier (LM) akan dibandingkan dengan distribusi chi-square, jika nilai $\chi^{2}$-statistik lebih besar dari $\chi^{2}$-tabel atau nilai peluang lebih kecil dari tingkat signifikansi $(\alpha=0.05)$ maka REM lebih baik dibandingkan dengan CEM.

Setelah didapat model terbaik, dilakukan uji asumsi klasik seperti uji normalitas, heteroskedastisitas, non-autokorelasi, dan non-multikolinieritas. Setelah memenuhi semua ui asumsi klasik dilakukan uji kesesuaian model / uji statistik dengan melihat nilai $\mathrm{R}^{2}$, adjusted $\mathrm{R}^{2}$, uji F dan uji t.

\section{HASIL DAN PEMBAHASAN}

Uji Estimasi Model

Pengaruh variabel PDRB perkapita, rasio panjang jalan raya terhadap luas wilayah provinsi, dan Indeks pembangunan teknologi informasi dan komunikasi terhadap pembangunan manusia dengan menggunakan fixed effect model. Hasil tersebut diperoleh dengan melalui Uji Chow, Uji Hausman dan Lagrange Multiplier. 
1. Uji Chow

Tabel 2. Uji Chow

\begin{tabular}{rcc}
\hline Effects Test & d.f. & Prob. \\
\hline \hline Cross-Section F & $(33,133)$ & 0.0000 \\
Cross-section Chi-Square & 181.43 & 0.0000 \\
\hline
\end{tabular}

Pada tabel terlihat bahwa nilai Prob. F dan Chi Square sebesar 0,0000 yang nilainya dibawah nilai alpha yaitu 0,05 sehingga dapat disimpulkan bahwa Fixed Effect Model atau model FE lebih tepat dibandingkan dengan Common Effect Model atau PLS.

2. Uji Hausman

Tabel3. Uji Hausman

\begin{tabular}{|c|c|}
\hline Effects Test & Prob. \\
\hline Chi-Square & -16.81 \\
\hline
\end{tabular}

Pada tabel terlihat bahwa nilai Prob Chi-Square sebesar -16.81 yang nilainya di atas nilai alpha yaitu 0,05 sehingga dapat disimpulkan bahwa Random Effect Model atau model RE lebih tepat dibandingkan dengan Fixed Effect Model atau model FE.

3. Uji Lagrange Multiplier

Tabel 4. Uji Lagrange Multiplier

\begin{tabular}{ll}
\hline \multicolumn{1}{c}{ Effects Test } & Prob. \\
\hline \hline Chi-bar-Square & 0.0000 \\
\hline \hline
\end{tabular}

Dari hasil pengujian lagrange multiplier test diatas, dapat dilihat bahwa pada hasil tersebut memiliki Prob<chibarsquaresebesar 0,0000, lebih kecil dari 0,05 artinya $\mathrm{H}_{0}$ : CEM ditolak dan $\mathrm{H}_{1}$ : REM diterima. Sehingga kesimpulan yang dapat diambil adalah menggunakan model random effect.

\section{Uji Asumsi Klasik}

Pengujian asumsi klasik dimaksudkan untuk menghasilkan parameter yang bersifat BLUE (Best Linear Unbiased Estimator). Estimator yang dimiliki memiliki nilai harapan sesuai dengan nilai sesungguhnya. Pengujian yang dilakukan meliputi uji normalitas, uji multikolinieritas, uji heterokedastisitas, dan uji autokorelasi.

1. Uji Normalitas

Uji normalitas bertujuan untuk menguji apakah dalam model regresi, variabel pengganggu atau residual memiliki distribusi normal. Seperti diketahui bahwa uji $t$ dan F mengasumsikan nilai residual mengikuti distribusi normal. Jika asumsi ini dilanggar, maka uji statistik menjadi tidak valid. 
Tabel 5. Hasil Uji Normalitas dengan skewness/kurtosis

\begin{tabular}{llllll}
\hline \hline \multicolumn{1}{c}{ Variabel } & Obs & Pr (skewness) & Pr (kurtosis) & $\operatorname{Adj~Chi~}^{2}(2)$ & Prob >chi2 \\
\hline \hline PDRB & 65 & 0.8797 & 0.3900 & 0.78 & 0.6762 \\
Jalan & 65 & 0.1697 & 0.6860 & 2.13 & 0.3442 \\
IPTIK & 65 & 0.0460 & 0.8456 & 4.17 & 0.1245 \\
\hline \hline
\end{tabular}

Asumsi normalitas akan terpenuhi apabila nilai $\mathrm{Prob}>\mathrm{Chi}^{2}$ lebih besar dari nilai $\alpha$. Dari hasil pengujian normalitas menggunakan uji skewness/kurotsis residual, dapat dilihat bahwa nilai Prob $>\mathrm{Chi}^{2}$ diatas nilai alpha 0,05 untuk masing - masing variabel. Variabel PDRB bernilai 0,6762, Jalan bernilai 0,3442 dan nilai IPTIK 0,1245. Karena Prob $>\mathrm{Chi}^{2}$ lebih besar daripada alpha, maka data residual berdistribusi normal.

2. Uji Multikolinearitas

Uji multikolinieritas bertujuan untuk menguji apakah dalam suatu model regresi ditemukan adanya korelasi antar variabel independen. Dalam model regresi yang baik seharusnya tidak terjadi korelasi diantara variabel bebas.Variabel bebas dikatakan terbebas dari gejala multikolinieritas apabila nilai Variance Inflation Factor (VIF) kurang dari 10 dan nilai Tolerance (1/VIF) lebih dari 0,10.

Tabel 6. Hasil Uji Multikolinearitas

\begin{tabular}{lcc}
\hline \hline Variabel & VIF & 1/VIF \\
\hline \hline PDRB & 5.17 & 0.193427 \\
Jalan & 3.82 & 0.261937 \\
IPTIK & 1.86 & 0.538836 \\
\hline \hline Mean VIF & 3.61 & \\
\hline \hline
\end{tabular}

Berdasarkan tabel di atas, nilai Variance Inflation Factor (VIF) dari setiap variabel bebasnya menunjukkan nilai yang kurang dari 10 . Begitu juga dengan nilai $1 / \mathrm{VIF}$ yangbernilai lebih dari 0,10. Jadi dapat disimpulkan bahwa tidak ada gejala multikolinieritas antar variabel bebas dalam model regresi.

Karena model yang digunakan adalah Random Effect, maka tidak perlu dilakukan uji heterokedastisitas dan autokolerasi. Hal tersebut disebabkan karena model Random Effect sudah menggunakan metode General Least Square.

\section{Uji Goodness of fit model}

Uji hipotesis dangat penting dilakukan, tujuannya agar penelitian yang akan dilakukan dapat diterima secara ilmiah. Untuk mengetahui kelayakan model, berdasarkan ketiga estimasi model yang telah dilakukan yaitu Common Effect Model, Fixed Effect Model, dan Random Effect Model, maka didapatkan hasil sebagai berikut: 
Tabel 7. Perbandingan Hasil Ouput Estimasi Model

\begin{tabular}{|c|c|c|c|c|c|c|c|}
\hline Model & \multicolumn{2}{|c|}{ t-test } & \multicolumn{2}{|c|}{ F-test } & $\mathbf{R}^{2}$ & Coefficient & Constanta \\
\hline \multirow{3}{*}{$\begin{array}{l}\text { Common } \\
\text { Effect Model } \\
\text {-Jalan } \\
\text {-TIK }\end{array}$} & $P>(t)$ & $\mathbf{t}$ & Prob. & $\mathbf{F}$ & \multirow{3}{*}{0,8079} & \multirow{3}{*}{$\begin{array}{l}0,0401026 \\
0,124659\end{array}$} & \multirow{3}{*}{4,074636} \\
\hline & 0,0000 & 8,25 & \multirow{2}{*}{0,0000} & \multirow{2}{*}{130,7} & & & \\
\hline & 0,0000 & 7,50 & & & & & \\
\hline $\begin{array}{l}\text { Fixed Effect } \\
\text { Model }\end{array}$ & $P>(t)$ & $\mathbf{t}$ & Prob. & $\mathbf{F}$ & \multirow{3}{*}{0,8069} & \multirow{3}{*}{$\begin{array}{l}0,0271323 \\
0,0740769\end{array}$} & \multirow{3}{*}{4.131645} \\
\hline -Jalan & 0,0110 & 2,64 & \multirow{2}{*}{0,0000} & 130,1 & & & \\
\hline -TIK & 0,0000 & 12,54 & & 1 & & & \\
\hline $\begin{array}{l}\text { Random } \\
\text { Effect Model }\end{array}$ & $\mathbf{P}>(\mathbf{z})$ & $\mathbf{Z}$ & Prob. & $\mathbf{F}$ & \multirow{3}{*}{0,7929} & \multirow{3}{*}{$\begin{array}{l}0.0389515 \\
0.0724802\end{array}$} & \multirow{3}{*}{4.146917} \\
\hline -Jalan & 0,0000 & 5,50 & $0,00 \cap 0$ & 2816 & & & \\
\hline -TIK & 0,0000 & 12,34 & 0,0000 & 201,0 & & & \\
\hline
\end{tabular}

Berdasarkan perbandingan di atas, dilihat dari nilai uji t, uji f, koefisien determinan $\left(\mathrm{R}^{2}\right)$, coefficient dan constanta, random effect model adalah pendekatan yang sesuai dibandingkan dengan fixed effect model dan common effect model.

\section{Uji Regresi}

Uji t

Berikut merupakan hasil pengujian hipotesis dari penelitian ini yaitu:

Pengujian ini dilakukan untuk mengetahui seberapa besar pengaruh variabel bebas secara individual dalam menerangkan variabel terikat. Dalam penelitian ini akan dibuktikan pengaruh masing-masing dari variabel independen yaitu Jalan dan TIK terhadap variabel terikat yaitu IPM. Variabel independen dikatakan berpengaruh secara signifikan terhadap variabel dependen atau $\mathrm{H}_{0}: \beta_{\mathrm{xy}}=0$ dan $\mathrm{H}_{0}: \beta_{\mathrm{xy}} \neq 0$ diterima apabila nilai $\{\mathrm{p}>|\mathrm{z}|\}$ $<$ dari nilai alpha yaitu sebesar 0,05 atau $t$ test $>\mathrm{t}$ tabel, dalam penelitian ini menggunakan pengujian $t$ tabel satu arah karena hipotesis dalam penelitian ini sudah diketahui arahnya yaitu arah positif dan signifikan.

Dari tabel 7 diperoleh hasil variabel jalan terhadap variabel indeks pembangunan manusia. Hasil $\mathrm{P}>|\mathrm{z}|$ dari variabel jalan yaitu 0,000 , artinya $\mathrm{P}>|\mathrm{z}|$ lebih kecil dari nilai $\alpha$ sebesar 0,05. Sehingga variabel jalan berpengaruh secara signifikan terhadap variabel indeks pembangunan manusia atau $\mathrm{H}_{\mathrm{O} 1}: \beta_{\mathrm{x} 1 \mathrm{y}} \neq 0$ ditolak dan $\mathrm{H}_{\mathrm{O} 1}: \beta_{\mathrm{x} 1 \mathrm{y}}=0$ diterima. Hasil yang sama juga diperoleh oleh variabel TIK. Hasil $\mathrm{P}>|\mathrm{z}|$ dari variabel jalan yaitu 0,000 , artinya $\mathrm{P}>|\mathrm{z}|$ lebih kecil dari nilai $\alpha$ sebesar 0,05 . Sehingga variabel TIK berpengaruh secara signifikan terhadap variabel indeks pembangunan manusia atau $\mathrm{H}_{\mathrm{O}}$ : $\beta_{\mathrm{X} 1 \mathrm{y}} \neq 0$ ditolak dan $\mathrm{H}_{\mathrm{O} 1}: \beta_{\mathrm{X} 1 \mathrm{y}}=0$ diterima.

Uji F

Uji F pada dasarnya menunjukkan apakah semua variabel bebas yang dimasukkan kedalam model mempunyai pengaruh secara bersama-sama terhadap variabel dependen. Variabel bebas secara bersama-sama dikatakan berpengaruh signifikan terhadap variabel dependen atau $\mathrm{H}_{0}: \beta_{\mathrm{xy}}=0$ dan $\mathrm{H}_{0}: \beta_{\mathrm{xy}} \neq 0$ diterima apabila nilai $\{$ prob $>\mathrm{F}\}<$ dari nilai $\alpha$ sebesar 0,05 atau nilai Ftest $>$ Ftabel.

Pada tabel 7 diperoleh hasil prob $>$ F sebesar 0,0000, angka tersebut lebih kecil dari nilai $\alpha$ sebesar 0,05 dan nilai Ftest (Wald chi2) sebesar 281,56. Sedangkan nilai Ftabel dengan $\alpha$ sebesar 0,05 dan nilai df sebesar 63 (nilai n-k yaitu 68-5) diperoleh angka sebesar 2,97. Sehingga nilai Ftest > Ftabel. Maka secara bersama-sama variabel Jalan dan TIK 
berpengaruh secara signifikan terhadap Indeks Pembangunan Manusia atau $\mathrm{H}_{0}: \beta x y \neq 0$ diterima dan $\mathrm{H}_{0}: \beta \mathrm{xy}=0$ ditolak.

Untuk nilai koefisien determinasi $\left(\mathrm{R}^{2}\right)$ adalah 0,7929 atau $79,29 \%$. Artinya kemampuan variabel jalan dan TIK menjelaskan variabel IPM adalah sebesar 79,29\%. Sedangkan sisanya $20,71 \%$ dijelaskan oleh variabel lain di luar dari variabel penelitian. Artinya tingkat error yang dihasilkan dalam persamaan regresi dari hasil penelitian ini adalah sebesar 0,2071 atau $20,71 \%$. Hal ini berarti, jika terjadi perubahan satu unit pada variabel bebas, maka variabel terikat akan berubah sebesar satu unit dengan asumsi variabel lain konstan.

\section{Analisis Hipotesis Penelitian}

Berikut ini pembahasan hipotesis dalam penelitian:

Variabel Jalan memberikan hasil estimasi koefisien positif. Hasil t-test menunjukkan bahwa variabel Jalan memiliki pengaruh yang signifikan terhadap Indeks Pembangunan Manusia pada alpha sebesar5\% atau 0,05. Besarnya pengaruh Jalan terhadap IPM, dapat dilihat dari nilai koefisien regresi variabel Jalan yaitu 0,0389515 . Hal ini menunjukkan bahwa ketika Rasio Jalan terhadap luas wilayah mengalami kenaikan sebesar 1 persen, maka IPM akan mengalami kenaikan sebesar 0,0318382 persen.

Akses jalan di wilayah timur indonesia masih sangat diperlukan dalam menunjang akses antar daerah. Hal tersebut berdampah secara signifikan akan meningkatkan kualitas kesejahteraan, kualitas pendidikan, dan kualitas kesehatan.

Variabel TIK memberikan hasil estimasi koefisien positif. Besarnya pengaruh Jalan terhadap IPM, dapat dilihat dari nilai koefisien regresi variabel Jalan yaitu 0.0724802. Hal ini menunjukkan bahwa ketika Indeks Pembangunan TIKmengalami kenaikan sebesar 1 poin, maka IPM akan mengalami kenaikan sebesar 0.0724802poin.

Dilain sisi, pembangunan infrastruktur sekunder, saat ini TIK dianggap sudah sama pentingnya dengan akses dasar seperti jalan. Bahkan jika dilihat dari angka estimasi penelitian, TIK dianggap mempunyai peran yang lebih besar dibandingkan akses infrastruktur dasar dalam hal ini jalan penghubung antar daerah. Hal itu bisa saja terjadi jika TIK digunakan sebagai opsi lain jika akses jalan tidak memungkinkan dibangun dan digantikan dengan internet dan penggunaan teknologi canggih lainnya.

\section{Penutup \\ Kesimpulan}

Wilayah timur Indonesia masih tertinggal dibandingkan dengan wilayah barat, baik dari aspek ekonomi, pembangunan daerah bahkan pembangunan manusia. Beragam kebijakan sudah dilakukan oleh pemerintah agar dapat menekan angka kesenjangan yang masih terlalu lebar.

Kebijakan pembangunan infrastruktur yang dilakukan oleh pemerintah pusat di wilayah timur cukup memberikan dampak yang signifikan bagi pembangunan manusia. Hal tersebut dapat dilihat dari angka IPM yang terus naik dari tahun 2015 hingga 2019. Kebijakan pembangunan infrastruktur dasar hingga saat ini masih sangat diperlukan agar tersedianya akses kesejahteraan, pendidikan, dan kesehatan yang lebih baik.

Selain pembangunan jalan, akses terhadap teknologi informasi dan komunikasi juga di pandang penting, karena memberikan dampak yang signifikan, khususnya pembangunan manusia di wilayah timur Indonesia. TIK dapat menjangkau wilayah atau daerah yang sulit dijangkau selama ini. Arah pembangunan juga mulai dapat diarahkan kepada aset digital dan komunikasi khususnya bagi wilayah wilayah yang sulit dijangkau dengan akses transportasi karena dapat menghemat waktu dan biaya.

\section{Saran}

Bagi pemerintah pusat maupun pemerintah daerah, investasi dibidang TIK juga tidak kalah sama pentingnya dengan investasi dibidang infrastruktur dasar. Mengingat investasi TIK merupakan solusi yang baik selain infrastruktur karena lebih ekonomis, efektif dan efisien dalam menangkas biaya produksi. Untuk itu porsi anggaran bagi TIK sebaiknya ditingkatkan. 
Selain infrastruktur TIK, sarana pelatihan - pelatihanjuga perlu diselenggarakan sejalan dengan infrastrukturnya. Sehingga momentum ekonomi era revolusi industri 4.0 dapat dirasakan seluruh warga negara hingga pada akhirnya mengurangi ketimpangan antar wilayah di Indonesia.

\section{E. Daftar Pustaka}

Asongu, S and Sara le Roux. (2017).Enhancing ICT for inclusive human development in SubSaharan Africa, Technological Forecasting and Social Change, 118, (C), 44-54

Bankole, F.O.A, Shirazi, F. and Brown, I. (2011). Investigating the impact of ICT investments on human development. The Electronic Journal of Information Systems in Developing Countries, 48(1), hlm.1-19.

Bankole, F.O., Brown, I. and Osei-Bryson, K.M., (2011), May. The impact of ICT infrastructure on human development: an analysis of ICT-Use in SADC countries. In Proceedings of the 11th International Conference on Social Implications of Computers in Developing Countries, Kathmandu, Nepal.

Badan Pusat Statistik Jakarta Pusat, (2020). Statistik Indonesia Tahun 2010. Jakarta Pusat : Badan Pusat Statistik.

Badan Pusat Statistik Jakarta Pusat, (2019). Statistik Indonesia Tahun 2010. Jakarta Pusat : Badan Pusat Statistik.

Badan Pusat Statistik Jakarta Pusat, (2018). Statistik Indonesia Tahun 2010. Jakarta Pusat : Badan Pusat Statistik.

Badan Pusat Statistik Jakarta Pusat, (2017). Statistik Indonesia Tahun 2010. Jakarta Pusat : Badan Pusat Statistik.

Badan Pusat Statistik Jakarta Pusat, (2016). Statistik Indonesia Tahun 2010. Jakarta Pusat : Badan Pusat Statistik.

Colecchia, A and Paul Schreyer, .(2002).ICT Investment and Economic Growth in the 1990s: Is the United States a Unique Case? A Comparative Study of Nine OECD Countries, Review of Economic Dynamics, 5, (2), 408-442

Gujarati, D.N. (2009). Basic econometrics. Tata McGraw-Hill Education.

Minah, T., (2014). Politik Industrialisasi Di Korea Selatan (Studi Atas Peran Negara Dalam Pengembangan Teknologi Dan Industri Periode 1990-2002) (Bachelor's thesis, Fisip UIN Jakarta).

Mohanty, Amar Kumar. (2016). "Does Infrastructure Affect Human Development? Evidences from Odisha, India”.India: Journal of Infrastructure Development.

Morawczynski, O. and Ngwenyama, O. (2007). Unraveling the impact of investments in ICT, education and health on development: an analysis of archival data of five West African countries using regression splines. The Electronic Journal of Information Systems in Developing Countries, 29(1), hlm.1-15. 
Tanaka, A. (2012). "International Development Cooperation in the 21st Century and SouthSouth/Triangular Cooperation" in Scaling Up South-South and Triangular Cooperation. Kato, Hiroshi (Ed.). Tokyo: JICA Research Institute.

United Nations Development Programme (UNDP), (2019) . Human Development Report (HDR).

Yakunina, R.P.Bychkov, G.A.(2015). Correlation Analysis of the Components of the Human Development Index Across Countries. Procedia Economics and Finance 